\title{
LEASING SEBAGAI ALTERNATIF PEMBIAYAAN KAPAL BAGI NELAYAN KECIL DI KOTA PEKALONGAN ${ }^{1}$
}

\author{
${ }^{1}$ Siti Malikhatun Badriyah, ${ }^{2}$ Siti Mahmudah, ${ }^{3}$ Amiek Soemarmi \\ Fakultas Hukum Undip, Hp. 08122828339 \\ sitimalikhatun@live.undip.ac.id
}

\begin{abstract}
Indonesia has great potential in the development of capture fisheries. However, exploration of marine resources has not been carried out optimally. One area that has the potential of large capture fisheries is Pekalongan City. This study aims to uncover the background and implementation of leasing as an alternative financing for vessels for small fishermen. The research method used is a mixed method that combines quantitative and qualitative research with a legal pluralism approach. The results of the study show that fisheries are the primary sector which is a mainstay in the economic development of Pekalongan City and its surroundings. Ships are the main capital in fishing operations. However, there are still many fishermen, especially small fishermen in Pekalongan City who do not have their own vessels due to lack of capital. Leasing as financing for capital procurement can be an alternative to procuring vessels for small fishermen
\end{abstract}

Keywords: leasing; financing; small fishermen; ships; capital goods

\begin{abstract}
Abstrak
Indonesia memiliki potensi besar dalam pengembangan perikanan tangkap. Meskipun demikian eksplorasi sumber daya laut belum dapat dilakukan secara optimal. Salah satu daerah yang memiliki potensi perikanan tangkap yang besar adalah Kota Pekalongan. Penelitian ini bertujuan mengungkap latar belakang dan implementasi leasing sebagai alternatif pembiayaan kapal bagi nelayan kecil. Metode penelitian yang digunakan adalah mixed methode yang memadukan antara penelitian kuantitatif dan kualitatif dengan pendekatan legal pluralism. Hasil penelitian menunjukkan bahwa perikanan merupakan sektor primer yang menjadi andalan dalam perkembangan perekonomian Kota Pekalongan dan sekitarnya. Kapal merupakan modal utama dalam kegiatan operasional nelayan. Namun demikian masih banyak nelayan terutama nelayan kecil di Kota Pekalongan yang tidak memiliki kapal sendiri karena ketiadaan modal. Leasing sebagai pembiayaan dalam pengadaan modal dapat menjadi alternatif pengadaan kapal bagi nelayan kecil
\end{abstract}

Kata kunci: leasing; pembiayaan; nelayan kecil; kapal; barang modal

\footnotetext{
${ }^{1}$ Hasil Penelitian Riset Penerapan dan Pengembangan (RPP) Tahun 2018 yang berjudul Model Pembiayaan Untuk Pengadaan Kapal Bagi Nelayan Kecil Dalam Pengembangan Industri Perikanan (Studi Pada Masyarakat Pesisir Utara Jawa Tengah).
} 


\section{A. Pendahuluan}

\section{Latar Belakang}

Indonesia memiliki sumber daya kelautan yang besar baik kekayaan keanekaragaman hayati dan non hayati kelautan, sehingga memiliki potensi besar dalam pengembangan perikanan tangkap di perairan. Susilowati (2013)(1) mengemukakan bahwa peran sumberdaya perikanan tidak diragukan lagi sumbangannya bagi bangsa dan negara Indonesia. Selain sebagai sumber penghidupan masyarakat untuk lapangan kerja maka juga menjadi sumber nutrisi hewani dan penghasil devisa negara. Namun, potensi sumberdaya perikanan Indonesia belum dapat dikelola dan dimanfaatkan secara optimal dan arif. Lebih dari $80 \%$ potensi laut Indonesia belum dieksplorasi dan dikelola dengan baik. Salah satu daerah yang memiliki potensi perikanan tangkap yang besar adalah Kota Pekalongan. Kota Pekalongan merupakan salah satu Kota yang berada pada Pesisir Pantai Utara Jawa Tengah. Secara geografis, wilayah Kota Pekalongan terletak antara 60 50' 42" - 60 55' 44" Lintang Selatan dan 1090 37' 55" 1090 42' 19" Bujur Timur. Rencana Tata Ruang Wilayah Nasional (RTRWN) menetapkan Kota Pekalongan sebagai Pusat Kegiatan Wilayah (PKW). Sebagai PKW maka diharapkan Kota Pekalongan dapat berperan menjadi pusat pengembangan bagi wilayah di sekitarnya, yang meliputi Kabupaten Pekalongan dan Kabupaten Batang. Dalam sistem pengembangan wilayah Provinsi Jawa Tengah, RTRW Provinsi Jawa Tengah juga menetapkan Kota Pekalongan sebagai bagian dan simpul utama dari Kawasan Petanglong (Kawasan Kota Pekalongan, Kabupaten Batang dan Kabupaten Pekalongan). Kawasan Petanglong adalah kawasan strategis dari sudut kepentingan pertumbuhan ekonomi dan sektor unggulannya adalah pertanian, pariwisata, industri dan perikanan. Potensi ekonomi yang manjadi andalan Kawasan Petanglong meliputi sektor primer adalah perikanan; sektor sekunder adalah tekstil, batik, dan pengolahan ikan; serta sektor tersier adalah jasa dan perdagangan. Kondisi ini tentunya menjadikan Kota Pekalongan memiliki posisi yang sangat strategis (Pemerintah Kota Pekalongan, 2018). (2)

Karena perikanan merupakan sektor primer yang menjadi andalan dalam perkembangan perekonomian di Kota Pekalongan dan sekitarnya, maka hal tersebut mendorong pemerintah meningkatkan industri perikanan untuk peningkatan kesejahteraan nelayan. Nelayan memiliki mata pencaharian utama sebagai penangkap ikan di laut. Kapal merupakan modal utama dalam kegiatan operasional nelayan dalam pengembangan industri perikanan. Salah satu kegiatan utama dalam pengembangan industri perikanan ini adalah penangkapan ikan di laut oleh nelayan. Penangkapan ikan adalah kegiatan untuk memperoleh ikan di perairan yang tidak dalam keadaan dibudidayakan dengan alat atau cara apa pun, termasuk kegiatan yang menggunakan kapal untuk memuat, mengangkut, menyimpan, mendinginkan, menangani, mengolah, dan/atau mengawetkannya (Pasal 1 angka 5 Undangundang Nomor 31 Tahun 2004 yang diubah dengan Undang-undang Nomor 45 Tahun 2009 tentang Perikanan). Kapal perikanan adalah kapal, perahu, atau alat apung lain yang digunakan untuk melakukan penangkapan ikan, mendukung operasi penangkapan ikan, pembudidayaan ikan, pengangkutan ikan, pengolahan ikan, pelatihan perikanan, dan penelitian/eksplorasi perikanan (Pasal 1 angka 9 Undang-undang Nomor 31 Tahun 2004 Tentang Perikanan yang diubah dengan Undang-undang Nomor 45 Tahun 2009). Sebagai barang modal utama kapal menjadi salah satu faktor penentu keberhasilan pengembangan usaha dalam industri perikanan, termasuk bagi nelayan kecil. Penyediaan dana untuk pembiayaan suatu usaha dapat dilakukan oleh bank maupun lembaga non-bank, antara lain yang dilakukan oleh Lembaga Pembiayaan sebagaimana ditentukan dalam Perpres No. 9 Tahun 2009 tentang Lembaga Pembiayaan. Prinsip utama dalam pengadaan Lembaga 
Pembiayaan adalah untuk membantu pengusaha kecil dan menengah dalam pengadaan modal untuk kelangsungan usaha (Badriyah, 2016) (3). Salah satu Lembaga Pembiayaan adalah Perusahaan Pembiayaan (finance), yang diatur dalam Peraturan Menteri Keuangan Nomor 84/PMK.012/2006 Tentang Perusahaan Pembiayaan. Setelah adanya Otoritas Jasa Keuangan, segala sesuatu berkaitan dengan perijinan dan pengawasan tidak lagi dalam lingkup Kementerian Keuangan tetapi dalam lingkup Otoritas Jasa Keuangan. Hal ini diatur dalam Peraturan Otoritas Jasa Keuangan Nomor 28/POJK.05/2014 tentang Perizinan Usaha dan Kelembagaan Perusahaan Pembiayaan dan Peraturan Otoritas Jasa Keuangan Nomor 29/ POJK.05/2014 Tentang Penyelenggaraan Usaha Perusahaan Pembiayaan. Salah satu usaha Perusahaan pembiayaan adalah leasing. Pasal 1 angka 5 Peraturan Presiden Nomor 9 Tahun 2009 Tentang Lembaga Pembiayaan menyebutkan bahwa:

"Sewa Guna Usaha (leasing) adalah kegiatan pembiayaan dalam bentuk penyediaan barang modal baik secara sewa guna usaha dengan hak opsi (finance lease) maupun sewa guna usaha tanpa hak opsi (operating lease) untuk digunakan oleh Penyewa Guna Usaha (lessee) selama jangka waktu tertentu berdasarkan pembayaran secara angsuran."

Leasing merupakan alternatif yang menarik bagi para pengusahan, karena selama ini mereka cenderung menggunakan dana rupiah tunai untuk kegiatan operasional perusahaan. Melalui leasing pengusaha dapat memperoleh dana untuk membiayai pembelian barang-barang modal dengan jangka waktu pengembalian antara tiga tahun hingga lima tahun atau lebih (Sumual \& Afandi, 2016).(4)

Hubungan hukum dalam leasing dasarnya adalah perjanjian. Perjanjian leasing ini merupakan perjanjian yang tidak diatur dalam Kitab Undang-undang Hukum Perdata, sehingga dikategorikn sebagai perjanjian tidak bernama. Perjanjian leasing belum diatur secara khusus dalam peraturan perundang-undangan. Masuknya perjanjian leasing di Indonesia didasarkan pada asas kebebasan berkontrak.

Leasing dapat menjadi alternatif pembiayaan bagi nelayan kecil untuk pengadaan kapal sebagai barang modal untuk penangkapan ikan di laut dalam pengembangan usaha perikanan tradisional. Untuk mendorong perkembangan industri perikanan tradisional pemerintah melakukan berbagai upaya, salah satunya adalah melalui pemberian bantuan kapal yang dimulai pada tahun 2016. Dalam hal ini Menteri Kelautan dan Perikanan mengadakan kerjasama dengan Otoritas Jasa Keuangan (OJK) untuk memberikan bantuan kredit kepada nelayan (Ambari, 2015).(5) Peningkatan akses permodalan akan sangat membantu para nelayan dalam mengembangkan usahanya serta meningkatkan kesejahteraan keluarganya. Dalam praktik belum banyak Lembaga Pembiayaan yang memberikan pendanaan bagi pengadaan kapal bagi nelayan kecil. Perusahaan pembiayaan pada umumnya masih memberikan pembiayaan pada pengadaan mobil, motor, alat-alat berat, sedangkan untuk pengadaan kapal nelayan masih sangat kurang. Bahkan di Kota Pekalongan belum ada perusahaan pembiayaan yang memberikan pembiayaan dengan leasing untuk pengadaan kapal bagi nelayan kecil. Bahkan terdapat kerancuan leasing dengan pembiayaan konsumen. Pada sisi lain peningkatan kemampuan nelayan untuk menangkap ikan sangat tergantung pada kapal yang digunakan untuk melaut. Oleh karena itu penelitian ini sangat urgen untuik dilakukan.

Dari uraian dalam latar belakang penelitian terdapat permasalahan sebagai berikut.

1. Mengapa leasing dapat menjadi alternatif pembiayaan bagi nelayan kecil di Kota Pekalongan?

2. Bagaimana implementasi leasing dalam pengadaan kapal bagi nelayan kecil di Kota Pekalongan? 


\section{Kerangka Teori}

\section{a. Fungsi Kapal bagi Nelayan Kecil}

Perikanan adalah semua kegiatan yang berhubungan dengan pengelolaan dan pemanfaatan sumber daya ikan dan lingkungannya mulai dari praproduksi, produksi, pengolahan sampai dengan pemasaran yang dilaksanakan dalam suatu sistem bisnis perikanan (Pasal 1 angka 1 Undang-undang Nomor 31 Tahun 2004 yang diubah dengan Undang-undang Nomor 45 Tahun 2009). Pasal 25 ayat (1) UU Perikanan 2009 menentukan bahwa usaha perikanan dilaksanakan dalam sistem bisnis perikanan, meliputi praproduksi, produksi, pengolahan, dan pemasaran. Usaha perikanan adalah semua usaha perorangan atau badan hukum untuk menangkap atau membudidayakan ikan termasuk kegiatan menyimpan, mendinginkan atau mengawetkan ikan untuk tujuan komersial (Pasal 1 angka 1 Peraturan Pemerintah Nomor 54 Tahun 2002). Secara garis besar berdasarkan cara menghasilkan produknya, usaha perikanan dapat dibagi menjadi tiga jenis usaha yaitu usaha penangkapan, usaha budidaya dan usaha pengolahan (Soemarmi, 2016, 99)(6). Sebagai salah satu kegiatan yang dapat dilakukan dalam pengembangan industri perikanan, usaha penangkapan ikan di laut memiliki peran yang sangat menentukan. Penangkapan ikan di laut dilakukan oleh nelayan dengan menggunakan kapal. Kapal menjadi barang modal utama bagi nelayan dalam menangkap ikan di laut.

Nelayan adalah orang yang mata pencahariannya melakukan penangkapan ikan (Pasal 1 angka 10 Undang-undang Perikanan). Berdasarkan kepemilikan modal, nelayan dibedakan menjadi tiga kelompok, yaitu nelayan buruh, nelayan juragan dan nelayan perorangan. Nelayan buruh adalah nelayan yang bekerja dengan alat tangkap milik orang lain. Sebaliknya nelayan juragan adalah nelayan yang memiliki alat tangkap yang dioperasikan oleh orang lain. Nelayan perorangan adalah nelayan yang memiliki peralatan tangkap sendiri, dan dalam pengoperasiannya tidak melibatkan orang lain (Sofianti \& Suartini, 2016)(7). Dari ketiga kelompok ini, kemiskinan nelayan cenderung dialami oleh nelayan perorangan dan nelayan buruh karena kedua jenis kelompok itu jumlahnya mayoritas dan citra kemiskinan melekat pada kehidupannya (Fadilah, Abidin \& Kalsum, 2014) (8). Sebagian nelayan ini merupakan Nelayan Kecil. Nelayan Kecil adalah orang yang mata pencahariannya melakukan penangkapan ikan untuk memenuhi kebutuhan hidup sehari-hari yang menggunakan kapal perikanan berukuran paling besar 5 (lima) gross ton (GT). Kapal Perikanan adalah kapal, perahu, atau alat apung lain yang digunakan untuk melakukan penangkapan ikan, mendukung operasi penangkapan ikan, pembudidayaan ikan, pengangkutan ikan, pengolahan ikan, pelatihan perikanan, dan penelitian/eksplorasi perikanan (Pasal 1 angka 9 UU Perikanan).

Berdasarkan alat tangkapnya, kapal nelayan dapat dibedakan menjadi: 1) Kapal Long Liner, 2) Kapal Purse Seiner, 3) Kapal Pole and Liner, 4) Kapal Gillnet , 5) Kapal Trawler.

Kapal-kapal ikan tersebut terdiri dari kapal atau perahu berukuran kecil berupa perahu sampan (perahu tanpa motor) yang digerakkan dengan tenaga dayung atau layar, perahu motor tempel yang terbuat dari kayu hingga pada kapal ikan berukuran besar yang terbuat dari kayu, fibre glass maupun besi baja dengan tenaga penggerak mesin diesel. Jenis dan bentuk kapal ikan ini berbeda sesuai dengan tujuan usaha, keadaan perairan, daerah penangkapan ikan (fishing ground) dan lain-lain, sehingga menyebabkan ukuran kapal yang berbeda pula (Purbayanto, 2004)(9).

Dalam usaha penangkapan ikan di laut, kapal menjadi barang modal utama bagi nelayan untuk kegiatan operasional tersebut. Namun demikian tidak semua nelayan memiliki kapal, karena terbatasnya modal untuk memperoleh kapal. Oleh karena itu, kapal merupakan faktor kunci keberhasilan pengembangan usaha perikanan. Modal merupakan faktor produksi utama dalam 
suatu usaha. Modal ini sangat penting baik dalam memulai usaha maupun dalam pengembangan usaha (Badriyah, 2011)(10). Jackson dan Mc Connell (2017)(11), menyatakan modal atau barang-barang investasi berkaitan dengan keseluruhan bahan dan alat yang dilibatkan dalam proses produksi seperti alat (perkakas), mesin, perlengkapan, pabrik, gudang, pengangkutan, dan fasilitas distribusi yang digunakan memproduksi barang dan jasa bagi konsumen akhir.

Barang merupakan bagian dari kebendaan, yang diatur dalam Pasal 499 KUH Perdata, yang menyebutkan bahwa kebendaan adalah tiap-tiap barang dan tiaptiap hak yang dapat dikuasai oleh hak milik (eigendom). Dalam Black's Law Dictionary disebutkan bahwa capital is the total assets of a business, especially those that help generate profit. Dengan demikian, barang modal merupakan barang yang digunakan untuk keperluan menjalankan usaha.

\section{b. Leasing Sebagai Alternatif Pembiayaan}

Pada hakikatnya leasing merupakan salah satu cara pembiayaan yang mirip dengan kredit bank. Hanya bedanya leasing memberikan bantuan dalam bentuk barang modal, sedangkan bank memberikan bantuan berupa permodalan.

Menurut Anwari (1988) (12), Nahrowi (2013)(13) Leasing di Indonesia, (Ghalia Indonesia, Jakarta, 1988), Leasing mengalami perkembangan yang begitu pesat. Hal ini tidak terlepas dari beberapa keuntungan leasing: 1). Penghematan modal, 2). Sangat fleksibel, 3). Sebagai sumber dana, 4). On atau off balance sheet dalam perhitungan pajak, 5). Menguntungkan cash flow, 6). Menahan pengaruh inflasi, 7). Sarana kredit jangka menengah dan jangka panjang, 8). Dokumentasinya sangat sederhana, 9). Berbagai biaya yang ada dikelompokkan dalam satu paket.

Perjanjian leasing belum diatur secara khusus dalam peraturan perundangundangan. Peraturan yang ada masih bersifat administratif saja, sedangkan hak dan kewajiban para pihak belum ada ketentuan yang mengaturnya. Perjanjian leasing mempunyai kemiripan perjanjian sewamenyewa, perjanjian beli sewa, dan perjanjian jual beli dengan angsuran, namun ada beberapa karakteristik tertentu yang menjadikan perjanjian leasing tidak dapat dikategorikan sebagai perjanjian-perjanjian jenis tersebut. Unsur utama yang sangat membedakannya adalah:

1. Adanya hak opsi, yaitu hak bagi lessee pada akhir perjanjian leasing untuk memilih apakah akan melanjutkan leasing atau mengembalikan barang atau memiliki barang objek leasing ;

2. Hak milik atas benda yang menjadi obyek leasing baru beralih kepada Lessee apabila pada masa akhir perjanjian lessee menggunakan hak opsi untuk membeli objek leasing;

3. Merupakan kegiatan pembiayaan;

4. Untuk penyediaan barang modal.

Adanya perbedaan tersebut, maka perjanjian leasing merupakan perjanjian jenis baru yang mandiri (sui generis). Perjanjian ini termasuk perjanjian innominaat, karena tidak diatur secara khusus dalam KUH. Perdata. Masuknya perjanjian leasing ke Indonesia didasarkan pada asas kebebasan berkontrak (Pasal 1338 KUH Perdata). Di Amerika dan Eropa Leasing memiliki karakteristik khusus. Neuberger \& Döppner (2013)(14) mengemukakan bahwa empirical studies show that the use of leasing in the US and Europe depends on firm-specific characteristics such as size, age, leverage, probability of bankruptcy, profitability, ownership structure, investment opportunity sets and tax variables.

Hubungan hukum antara lessor dan lessee dalam leasing didasarkan pada perjanjian. Perjanjian merupakan hubungan hukum antara dua orang atau lebih berdasarkan kata sepakat yang menimbulkan akibat hukum. Pada umumnya perjanjian leasing dibuat dalam bentuk baku/standard. Nur Syaimasyaza Mansor \& Khairuddin Abdul Rashid (2013)(15) mengemukakan bahwa The use of a standard contract is 
very common in industry. Perjanjian leasing ini dibuat secara sepihak oleh Perusahaan leasing, sedangkan lessee hanya memiliki kesempatan untuk menerima atau menolak perjanjian tersebut.

\section{B. Metode Penelitian}

Untuk menjawab problematika penelitian digunakan metode mixed methode, yang memadukan penelitian kuantitatif dan kualitatif. Dalam hal ini menggunakan pendekatan legal pluralism, yang mengintegrasikan pendekatan (1) normatif (state law) dengan melihat peraturan-peraturan hukum tertulis yang berkaitan dengan pembiayaan untuk penyediaan kapal bagi nelayan kecil, (2) sosiologis (living law) yaitu mengungkap serta menganalisis praktik pelaksanaan pembiayaan yang berkembang dalam kehidupan masyarakat Pekalongan, dan mengungkap latar belakang diperlukannya leasing sebagai alternatif pembiayaan untuk pengadaan kapal bagi nelayan kecil dan (3) filosofis (religion, moral, ethic) dengan mengkaji dan menganalisis nilai-nilai, asasasas yang ada di dalam masyarakat yaitu nelayan kecil di pesisir Kota Pekalongan. Dalam hal ini dilakukan penelitian kepustakaan dengan teknik studi dokumen, serta penelitian lapangan dengan teknik wawancara. Wawancara ini dilakukan dengan wawancara mendalam terhadap informan yaitu nelayan kecil di Kota pekalongan dengan teknik pengambilan sampel secara snowball. Di samping itu juga dilakukan wawancara mendalam dengan narasumber dan informan dengan teknik pengambilan sampel secara purposive sampling terhadap Otoritas Jasa Pembiayaan dan Lembaga Pembiayaan. Teknik analisis data dengan menggunakan analisis kualitatif, dan pengujian data dengan menggunakan triangulasi sumber maupun metode.
C. Hasil Penelitian dan Pembahasan

1. Latar Belakang Leasing sebagai Alternatif Pembiayaan untuk Pengadaan Kapal bagi Nelayan Kecil di Kota pekalongan

Tingkat konsumsi ikan Indonesia meningkat sebesar $21.9 \%$ sepanjang periode 2014-2017. Pada tahun 2014 jumlah konsumsi ikan mencapai 38,14 $\mathrm{kg} / \mathrm{kapita} / \mathrm{tahun}$. Jumlah konsumsi tersebut meningkat pada tahun 2015 menjadi 41,11 $\mathrm{kg} / \mathrm{kapita} / \mathrm{tahun}$. Peningkatan konsumsi ikan juga terjadi pada tahun 2016 menjadi 43,94 $\mathrm{kg} / \mathrm{kapita} / \mathrm{tahun}$. Pada tahun 2017 tercatat angka konsumsi ikan telah mencapai 47,34 $\mathrm{kg} / \mathrm{kapita} / \mathrm{tahun}$. Gambar 10 menunjukkan perkembangan angka konsumsi ikan Indonesia dari tahun 2014-2017.

Peningkatan konsumsi ikan ini menunjukkan kebutuhan akan ikan menjadi makin meningkat. Oleh karena itu peningkatan produksi ikan harus terus dikembangkan di berbagai daerah di wilayah Indonesia. Salah satu daerah yang menjadi penghasil ikan adalah Kota Pekalongan.

Sebagaimana telah dikemukakan pada bagian pendahuluan bahwa Pekalongan memiliki potensi perikanan yang menjadi andalan primer bagi pengembangan perekonomian. Letak Pekalongan sangat strategis. Bahkan dalam sistem pengembangan wilayah RTRW Provinsi Jawa Tengah menetapkan Kota Pekalongan sebagai bagian dan simpul utama dari Kawasan Petanglong (Kawasan Kota Pekalongan, Kabupaten Batang dan Kabupaten Pekalongan). Batas administratif Kota Pekalongan adalah sebagai berikut:

a. Sebelah Utara berbatasan dengan Laut Jawa;

b. Sebelah Timur berbatasan dengan Kabupaten Batang;

c. Sebelah Selatan berbatasan dengan Kabupaten Batang dan Pekalongan; dan

d. Sebelah Barat berbatasan dengan Kabupaten Pekalongan

Luas wilayah Kota Pekalongan adalah $4.525 \mathrm{Ha}$ atau $45,25 \mathrm{~km} 2$. Jarak terjauh dari wilayah Utara ke wilayah Selatan $\pm 9 \mathrm{Km}$ dan dari wilayah Barat ke wilayah Timur \pm 7 
Km. Kota Pekalongan terdiri dari 4 kecamatan dan pada mulanya 47 kelurahan menjadi 27 kelurahan. Sesuai dengan Peraturan Daerah Nomor 8 Tahun 2013 tentang Penggabungan Kelurahan di Lingkungan Pemerintah Kota Pekalongan, secara administratif Kota Pekalongan terbagi menjadi 4 kecamatan dan 27 kelurahan (diberlakukan per 1 Januari 2015).

Kota Pekalongan yang mempunyai garis pantai sepanjang $6,15 \mathrm{~km}$ merupakan salah satu kota di Indonesia yang memiliki Pelabuhan Perikanan yang cukup besar dengan type $\mathrm{B}$, yang dilengkapi dengan Tempat Pelelangan Ikan (TPI) sebagai pusat kegiatan dan transaksi hasil tangkapan ikan. Kedua fasilitas tersebut mendorong aktivitas perekonomian di Kota Pekalongan bergerak cukup baik, seperti perdagangan, pabrik es, pengolahan ikan, pergudangan, transportasi pengangkutan barang, maupun kegiatan ekonomi yang lain.

Sebagai daerah yang berbatasan langsung dengan laut, Kota Pekalongan memiliki potensi alam kelautan berupa produksi ikan laut yang dapat dikembangkan menjadi sumber pendapatan daerah dan mata pencaharian masyarakat, serta dapat diandalkan sebagai komoditas ekspor dalam bentuk produk olahan ikan laut. Potensi sumber daya perikanan di perairan bagian utara Kota Pekalongan didominasi sumber daya ikan kecil, yaitu ikan-ikan yang hidup di permukaan laut atau didekatnya, dan umumnya terdiri dari ikan-ikan yang berukuran relatif kecil seperti ikan kembung, ikan layar, ikan selar, ikan bentong, ikan lemuru, ikan tembang dan lain-lain.

Perikanan menjadi salah satu sub sektor andalan dalam usaha sektor pertanian di Kota Pekalongan. Hal ini ditunjukkan pada angka PDRB Kota Pekalongan yang selama kurun waktu 7 tahun terakhir ini, subsektor perikanan mempunyai nilai tambah tertinggi dibandingkan dengan subsektor pertanian lainnya seperti tanaman pangan maupun peternakan.
Tabel 1

Produksi Ikan Laut Kota Pekalongan Tahun 2015-2016

\begin{tabular}{c|cccc}
\hline Tahun & 2015 & $\begin{array}{c}2015 \\
\text { (Seme }\end{array}$ & $\begin{array}{c}2016 \\
\text { (Seme }\end{array}$ & $\begin{array}{c}2016 \\
\text { (Seme } \\
\text { ster II) }\end{array}$ \\
\hline $\begin{array}{c}\text { Volu } \\
\text { me } \\
\text { ster I) }\end{array}$ & $\begin{array}{c}7.625, \\
\text { ster II) }\end{array}$ & 9.956, & 10.693 & 9.913, \\
(Ton) & 66 &, 52 & 87 \\
$\begin{array}{c}\text { Harga } \\
\text { (Rupi } \\
\text { ah) }\end{array}$ & 90,38 & 103,27 & 155,67 & 123,53 \\
milyar & milyar & milyar & milyar \\
\hline \multicolumn{5}{c}{ Sumber: Pemerintah Kota Pekalongan } \\
\multicolumn{5}{c}{ Bagian Perikanan dan Kelautan }
\end{tabular}

Pada semester I Tahun 2016 mencapai 10.693,52 ton, dengan nilai Rp. 155,67 milyar, lebih tinggi 40,23\% dibandingkan tahun 2015 sebanyak 7.625,68 ton dengan nilai Rp 90,38 milyar. Pada bulan Februari, produksi ikan tercatat paling rendah bila dibandingkan dengan bulan lain pada Semester I 2016, yaitu hanya 1.303,57 ton dengan nilai Rp. 15,97 milyar. Produksi tertinggi terjadi pada bulan Januari, sebanyak 2.500,42 ton dengan nilai $\mathrm{Rp}$. 29,97 milyar. Berdasarkan wawancara dan data dari Pemerintah Kota Pekalongan dapat diketahui bahwa produksi ikan laut pada semester II Tahun 2016 mencapai 9.913,87 ton, dengan nilai mencapai $\mathrm{Rp} 123,53$ milyar rupiah, jumlahnya lebih rendah $0,43 \%$ bila dibandingkan dengan Tahun 2015, sebanyak 9.956,66 ton dengan nilai Rp 103,27 milyar. Pada bulan Agustus, produksi tercatat paling rendah bila dibandingkan dengan bulan lain pada semester II Tahun 2016, yaitu hanya 220,54 ton dengan nilai Rp 7,94 milyar. Produksi tertinggi terjadi pada bulan Oktober, mencapai 3.752,38 ton dengan nilai $\mathrm{Rp}$ 41,06 milyar. Produksi ikan laut di Kota Pekalongan pada tahun 2015 mengalami penurunan, sedangkan pada tahun 2016 mengalami kenaikan pesat sebagaimana dapat dilihat dalam tabel 2 . 
Tabel 2

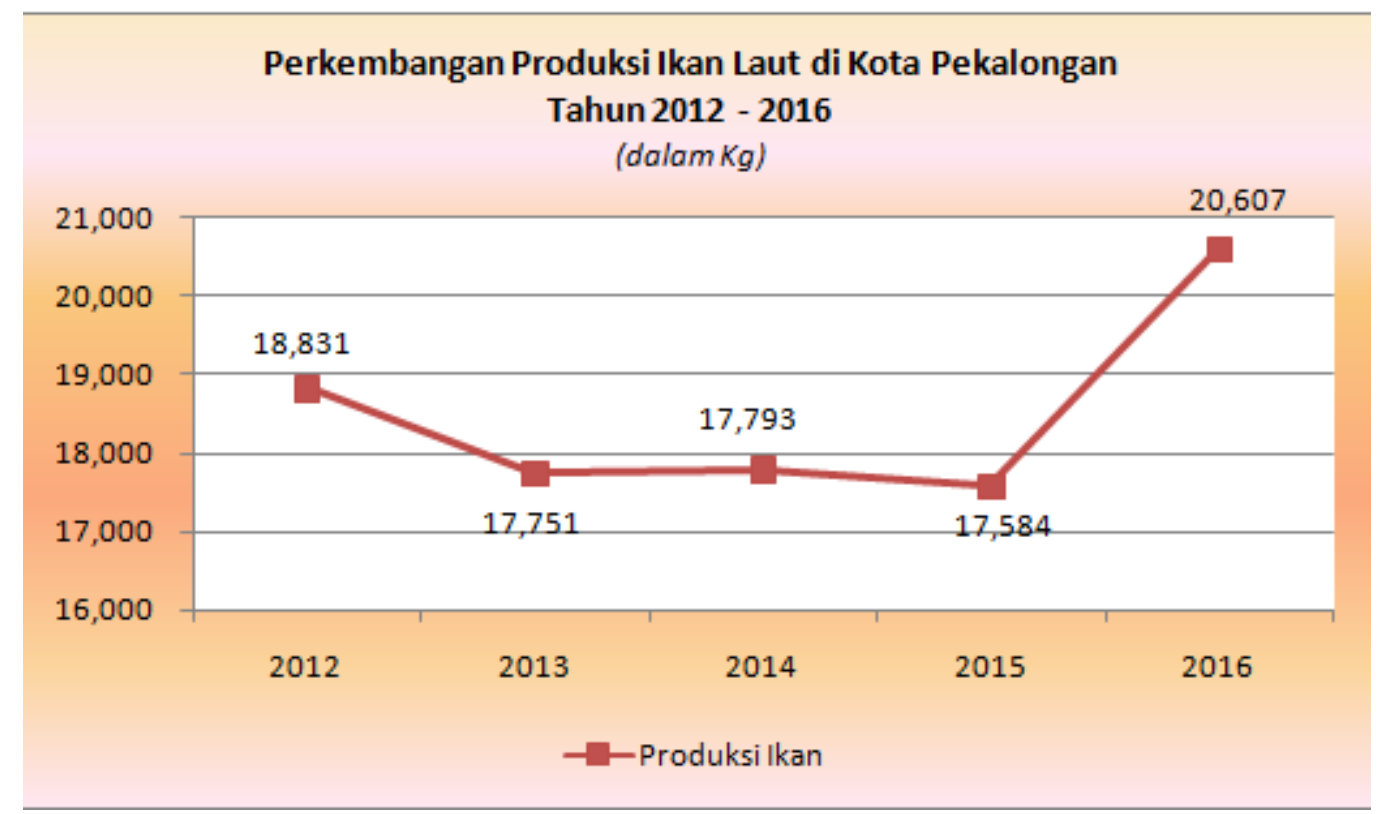

Sumber: Pemerintah Kota Pekalongan Bagian Perikanan dan Kelautan

Dalam pengembangan industri perikanan berbagai sarana dan prasarana yang mendukung telah disiapkan Pemerintah Kota Pekalongan agar dapat menunjang usaha penangkapan, pendaratan sampai pelelangan ikan dan pengelolaan hasil tangkapan serta memperlancar rantai pemasaran. Namun upaya pemerintah belum mencukupi untuk memenuhi seluruh kebutuhan nelayan di Kota Pekalongan. Sampai saat ini masih banyak nelayan, terutama nelayan kecil yang mengalami kesulitan untuk memperoleh pembiayaan untuk memenuhi kebutuhan dalam penangkapan ikan di laut. Salah satunya dalam memperoleh pembiayaan dari lembaga pembiayaan untuk pengadaan kapal. Hal ini karena masih terdapat keengganan bagi Perusahaan Pembiayaan untuk membiayai pengadaan kapal bagi nelayan kecil, hal ini karena adanya risiko yang besar bagi perusahaan pembiayaan. Padahal dalam usaha penangkapan ikan di laut, kapal menjadi barang modal utama bagi nelayan untuk kegiatan operasional. Oleh karena itu, kapal merupakan faktor kunci keberhasilan pengembangan usaha perikanan. Modal merupakan faktor produksi utama dalam suatu usaha. Modal ini sangat penting baik dalam memulai usaha maupun dalam pengembangan usaha.
Namun demikian tidak semua nelayan memiliki kapal, karena terbatasnya modal untuk memperoleh kapal.

Leasing dapat menjadi alternatif pembiayaan bagi nelayan kecil untuk pengadaan kapal sebagai barang modal untuk penangkapan ikan di laut dalam pengembangan usaha perikanan tradisional. Untuk mendorong perkembangan industri perikanan tradisional pemerintah melakukan berbagai upaya, salah satunya adalah melalui pemberian bantuan kapal yang dimulai pada tahun 2016. Dalam hal ini Menteri Kelautan dan Perikanan mengadakan kerjasama dengan Otoritas Jasa Keuangan (OJK) untuk memberikan bantuan kredit kepada nelayan (M. Ambari, 2015)(5). Peningkatan akses permodalan akan sangat membantu para nelayan dalam mengembangkan usahanya serta meningkatkan kesejahteraan keluarganya.

Kapal nelayan merupakan barang modal utama bagi nelayan dalam menangkap ikan di laut. Sebagai barang modal maka sangat tepat apabila pengadaannya dengan menggunakan leasing. Hal ini sesuai dengan Pasal 1 angka 5 Peraturan Presiden Nomor 9 Tahun 2009 Tentang Lembaga Pembiayaan bahwa leasing merupakan pembiayaan dalam bentuk penyediaan barang modal. 
Pembayaran barang modal dalam leasing dilakukan secara angsuran. Hal ini sesuai dengan Pasal 1 angka 5 Peraturan Presiden Tentang Lembaga Pembiayaan. Sistem angsuran ini akan memberikan kemudahan bagi nelayan karena tidak harus klangsung mengeluarkan uang dalam jumlah yang sangat besar untuk memperoleh kapal. Dengan demikian leasing dapat menjadi alternatif bagi nelayan kecil untuk pemgadaan kapal.

Sebagai alternatif pembiayaan untuk pengadaan kapal bagi nelayan kecil, dapat dilakukan dengan dua metode leasing, baik leasing dengan hak opsi maupun tanpa hak opsi. Hal tersebut sesuai dengan Pasal 1 angka 5 Peraturan Presiden tentan Lembaga Pembiayaan.

Hubungan hukum dalam leasing dasarnya adalah perjanjian. Perjanjian leasing belum diatur secara khusus dalam peraturan perundang-undangan. Masuknya perjanjian leasing didasarkan pada asas kebebasan berkontrak.

Leasing merupakan bisnis loosely regulated tidak seperti lembaga keuangan bank, maka perlindungan hukum terhadap para pihak sangat minim hanya sebatas itikad baik dari para pihak itu sendiri yang kemudian dituangkan dalam suatu perjanjian(16).

Karena belum ada aturan khusus mengenai perjanjian leasing, maka berlaku ketentuan umum perjanjian di dalam Kitab Undang-undang Hukum Perdata (K.U.H. Perdata) yang mengakomodasi perjanjian bernama maupun perjanjian tidak bernama. Pasal 1319 K.U.H. Perdata menyebutkan bahwa semua perjanjian, baik yang mempunyai nama khusus, maupun yang tidak dikenal dengan suatu nama tertentu, tunduk pada peraturan-peraturan umum, yang termuat dalam K.U.H. Perdata.

Sebagaimana dikemukakan di atas, perjanjian leasing merupakan perjanjian tidak bernama karena tidak diatur secara khusus dalam K.U.H. Perdata, dan pengaturannya belum ada. Oleh karena itu terhadap perjanjian leasing maka berlaku ketentuan umum mengenai perjanjian dalam K.U.H. Perdata (Pasal 1319 K.U.H. Perdata).

2. Implementasi Leasing dalam Pengadaan Kapal bagi Nelayan Kecil di Kota Pekalongan

Sistem leasing memberikan peluang menarik bagi pengusaha, karena mempunyai keunggulan-keunggulan sebagai alternatif pembiayaan di luar sistem perbankan, antara lain.

a) Proses pengadaan peralatan modal relatif lebih cepat dan tidak memerlukan jaminan kebendaan, prosedurnya sederhana dan tidak ada keharusan melakukan studi kelayakan yang memakan waktu lama;

b) Pengadaan kebutuhan modal alat-alat berat dan mahal dengan teknologi tinggi sangat meringankan terhadap kebutuhan cash flow mengingat sistem pembayaran angsuran berjangka panjang;

c) Posisi cash flow perusahaan akan lebih baik dan biaya-biaya modal menjadi lebih murah dan menarik;

d) Perencanaan keuangan perusahaan lebih mudah dan sederhana.

Dalam praktik, leasing mengalami perkembangan pesat. Namun demikian belum banyak Lembaga Pembiayaan yang memberikan pendanaan bagi pengadaan kapal bagi nelayan kecil. Perusahaan pembiayaan pada umumnya masih memberikan pembiayaan pada pengadaan mobil, motor, alat-alat berat, sedangkan untuk pengadaan kapal nelayan masih belum mendapat perhatian. Pada sisi lain peningkatan kemampuan nelayan untuk menangkap ikan ini sangat tergantung pada kapal yang digunakan untuk melaut. Kapal menjadi modal utama bagi nelayan untuk menangkap ikan di laut. Oleh karena leasing dapat menjadi alternatif model pembiayaan dalam pengadaan kapal bagi nelayan kecil dalam pengembangan usaha perikanan tradisional sangat urgen untuk dilakukan.

Di Pekalongan belum ada nelayan kecil yang menggunakan jasa pembiayaan leasing untuk pengadaan kapal. Hal ini karena 
masih belum banyak nelayan kecil yang mengetahui pembiayaan dengan cara leasing untuk pengadaan kapal. Di samping itu adanya keengganan dari perusahaan pembiayaan untuk membiayai kapal bagi nelayan kecil karena tidak adanya jaminan yang memadai. Apabila kapal yang dibiayai tersebut menjadi jaminan terdapat risiko besar bagi perusahaan pembiayaan, karena sewaktu-waktu bisa mengalami kecelakaan di laut, dan nilai kapal juga cenderung terus mengalami penurunan dengan cepat.

Berdasarkan kondisi sebagaimana telah diuraikan di atas maka pada masa mendatang diperlukan konstruksi perjanjian leasing yang dapat lebih memberikan perlindungan hukum bagi para pihak.

1. Perlu adanya peraturan khusus mengenai perjanjian leasing untuk memberikan perlindungan hukum terhadap para pihak.

2. Perlu adanya sosialisasi secara massif mengenai leasing untuk pengadaan barang modal kepada Perusahaan Pembiayaan maupun Nelayan.

3. Perlu adanya leasing dengan jaminan dari pemerintah (state guarantee) bagi nelayan kecil dalam pengadaan kapal sebagai barang modal untuk pengembangan industri perikanan untuk meningkatkan kesejahteraan nelayan.

\section{Simpulan}

1. Kota Pekalongan memiliki potensi besar dalam pengembangan industri perikanan tangkap, namun masih banyak nelayan kecil yang mengalami kendala dalam pengadaan kapal sebagai barang modal. Leasing dapat menjadi alternatif bagi nelayan kecil dalam pengadaan kapal bagi nelayan karena prosesnya sederhana dan cepat. Di samping itu sistem pembayaran secara angsuran lebih akan memberikan keringanan dalam pembayaran.

2. Di Kota Pekalongan belum ada nelayan kecil yang memperoleh pembiayaan untuk pengadaan kapal dengan cara leasing, karena kurangnya pengetahuan masyarakat mengenai leasing untuk pengadaan kapal. Di samping itu lembaga pembiayaan enggan untuk memberikan pembiayaan bagi pengadaan kapal karena menganggap risiko bagi perusahaan pembiayaan terlalu besar, dan nilai kapal juga cepat mengalami penurunan.

\section{DAFTAR PUSTAKA}

\section{A. Buku, Makalah, Jurnal, Website}

Susilowati, I. (2013).Prospek Pengelolaan Sumber Daya Perikanan Berbasis Ekosistem: Studi Empiris Di Karimunjawa. Jurnal Ekonomi Pembangunan. Vol.14(1). pp. 16-37. Available from: file:///C:/Users/user/Documents/Ejournal/Fishing Industry/industri perikanan jawa/PROSPEK PENGELOLAAN SUMBER DAYA PERIKANAN.pdf\%0D

Pemerintah

Kota

Pekalongan.(

Pekalongan, Kota Pekalongan.

Badriyah SM. (2016). Dilemma's Use of Leasing Agreement Object as Fiduciary Guarantee Object. In: International Conference on Law, Business, and Social Justice (IC-LBSJ 2016), "Encouraging a Better ASEAN Community Relationship. Yogyakarta: Universitas Atma Jaya.

Sumual M, Afandi D. (2016). Analisis Perlakuan Akuntansi Leasing Dan Pelaporannya Pada PT. Astra Sedaya Finance Di Manado. Jurnal Berkala Ilmiah Efisiensi. Vol. 16. pp. 636-646.

Ambari M.(2015). Skema Perlindungan Nelayan Wajib Ada dalam RUU Perlindungan Nelayan. Retrieved from: www. Mongabay.co.id.

Soemarmi A. (2016). Buku Ajar Hukum Perikanan,. 1st ed. Semarang: UNDIP Press. pp. 99

Sofiyanti N, Suartini S. (2016) Pengaruh Jumlah Kapal Perikanan Dan Jumlah Nelayan Terhadap Hasil Produksi Perikanan Di Indonesia. journal.unsika.ac.id Vol.1(No. 1). 
pp.49-61. Retrieved from: https://journal.unsika.ac.id/index.php/ac counthink/article/

Fadilah, Abidin Z, Kalsum U. (2014). Pendapatan Dan Kesejahteraan Rumah Tangga Nelayan Obor Di Kota Bandar Lampung. jurnal.fp.unila (JIIA). Vol.2. (No. 1 Januari): pp.71-76. Retrieved from:

jurnal.fp.unila.ac.id/index.php/JIA/articl e/download/563/525

Purbayanto. (2004). Kajian Teknis Kemungkinan Pengalihan Pengaturan Perijinan dari GT menjadi Volume Palka pada Kapal Ikan. "Paradigma Baru Pengelolaan Perikanan yang Bertanggungjawab dalam Rangka Mewujudkan Kelestarian Sumberdaya dan Manfaat Ekonomi Maksimal" 1011 Mei 2004.

Badriyah SM. (2014). The Breeding of The Contract Law Principles (The Study of The Leasing Agreement in Civil Law and Common Law System). South East Asia Journal Contemporary Business, Economics and Law. Vol. 6 (Issue 4 April).

Jackson, Connell M. No Title. Retrieved from: http//www. forumbebas.com

Anwari A. (1988). Leasing di Indonesia. Jakarta: Ghalia Indonesia, pp. 9-10.

Nahrowi. (2013). Permasalahan Hukum Pembiayaan Leasing Di Indonesia. Jurnal Cita Hukum. Vol. I (No.1 Juni). pp.25-38.

Neuberger D, Räthke-Döppner S. (2013). Leasing by Small Enterprises. Applied Financial Economics Journal Vol. 23 (issue 7). pp. 535-49. Retrieved from: http://dx.doi.org/10.1080/09603107.201 $2.730132,2013$

Mansor NS, Rasyid KA.(2016). Incomplete Contract in Private Finance Initiative (PFI) Contracts: Causes, Implications and Strategies. Elsevier, Procedia Social and Behavioral Sciences www.sciencedirect.com. Vol.222, pp. 93-102. Retrieved from: www.sciencedirect.com

Kambey SF. (2015). Perlindungan Hukum Terhadap Perusahaan Pembiayaan Dalam Perjanjian Leasing. J Ilmu Huk Leg Opin. Vol. 3.(No. 3). pp. 1-9.

\section{B. Peraturan Perundangundangan}

Kitab Undang-undang Hukum Perdata

Undang-undang Nomor 31 Tahun 2004 tentang Perikanan

Undang-undang Nomor 45 Tahun 2009 Tentang Perubahan atas Undangundang Nomor 31 Tahun 2004 tentang Perikanan

Perpres No. 9 Tahun 2009 tentang Lembaga Pembiayaan

Peraturan Otoritas Jasa Keuangan Nomor 28/POJK.05/2014 tentang Perizinan Usaha dan Kelembagaan Perusahaan Pembiayaan.

Peraturan Otoritas Jasa Keuangan Nomor 29/ POJK.05/2014 Tentang Penyelenggaraan Usaha Perusahaan Pembiayaan.

Peraturan Menteri Keuangan Nomor 84/PMK.012/2006 Tentang perusahaan pembiayaan. 